\title{
The Role of Transformational Leadership toward Work Performance through Intrinsic Motivation: A Study in the Pharmaceutical Field in Vietnam
}

\author{
Ha Minh NGUYEN ${ }^{1}$, Lam Tung MAI ${ }^{2}$, Tam Luong HUYNH ${ }^{3}$
}

Received: July 16, 2019 Revised: September 16, 2019 Accepted: September 30, 2019

\begin{abstract}
The study aims to identify the role of transformational leadership toward work performance through intrinsic motivation in pharmaceutical field by a survey of 220 pharmacists in Vietnam. The pharmaceutical industry in Vietnam is experiencing rapid growth, accompanied by the need for a change in leadership for managers. The transformational leadership creates a proactive, positive attitude, passion, interest or an increase in intrinsic motivation of employees, thereby affecting work performance. This study performed reliable verification by Cronbach's Alpha coefficient, then the factors are analyzed by EFA before conducting multivariate regression analysis. The results showed that the transformational leadership style includes such factors as: idealized influence (attributed and behavior), inspirational motivation, intellectual stimulation, individualized consideration have a positive impact on intrinsic motivation and thereby positively affecting work performance. It confirms that employees will have a higher intrinsic motivation level when working under transformational leadership from their leaders. It makes employees work more efficiently. According to the research results, the pharmacist has an intrinsic motivation to work hard on tasks that contribute to the group overall goal of. That requires managers to have a task assignment strategy to connect the goals of the members together as well as of the members to the group.
\end{abstract}

Keywords : Leadership Style, Transformational Leadership, Instrinsic Motivation, Work Performance, Pharmaceutical Industry

JEL Classification Code : M12, L65, L25

\section{Introduction}

According to IMS Health, Vietnam's pharmaceutical industry belongs to a group of 21 countries which have a growing pharmaceutical industry. Total expenditure per capita for drugs in Vietnam in 2013 reached 33 USD/person. Although Vietnam has only reached the level of production of completed medicines from imported materials, it has not been able to produce pharmaceutical raw materials by itself and has

1 First Author and Corresponding Auhtor, Rector, Ho Chi Minh City Open University, Vietnam. [Portal Address: 97 Vo Van Tan Street, District 3, Ho Chi Minh City, 700000, Vietnam]

Email: ha.nm@ou.edu.vn or ngmiha2014@gmail.com

2 Ho Chi Minh City Open University, Vietnam.

3 Ph.D. Student, Ho Chi Minh City Open University, Vietnam. Email: tamhl.18ab@ou.edu.vn

(c) Copyright: Korean Distribution Science Association (KODISA)

This is an Open Access article distributed under the terms of the Creative Commons Attribution Non-Commercial License (http://Creativecommons.org/licenses/by-nc/4.0/) which permits unrestricted noncommercial use, distribution, and reproduction in any medium, provided the original work is properly cited. not yet invented drugs but Vietnam has the highest growth rate in Southeast Asia in the 2008 - 2012 period reaching 23\% per year. Though while the economic crisis brought down most economic sectors," the pharmaceutical industry still achieved good growth. Along with the average population growth of Vietnam at $2 \%$ per year and gradually aging population structure, the demand for drugs is increasing, it is expected that the growth will increase about $17 \%$ per year.

Unlike other business sectors, the pharmaceauticals industry is an special economic and technical field because it is directly related to human health. Therefore, the sales and marketing team Not only need to gain certain knowledge, they also have a certain expertise in pharmaceuticals. The direct customers of the pharmacist is doctors, who are not directly using medicines but having an important impact on the patient's use with prescription behavior. The working time of the pharmacist is often flexible, depending on the doctor's free time, so the pharmacist needs to have high self-awareness in working, proactively addressing real situations. The leader with 
transformational leadership style is the person who has the ability to set clear and specific goals for employees, encourage employees, inspire the vision for employees, thereby creating the breakthrough in work.

In Vietnam, the bonus usually accounts for $40-60 \%$ of the pharmacis's income. This is high when comparing to other industries. This creates extrinsic motivations to help the pharmaceuticals become commit and contribute to the company. However, according to Towers Watson, a consulting company, the average job quits rate in 2014 of Vietnamese enterprises was 10\%; in more detail pharmaceuticals and banking - financial are the sectors that made up the highest rate. The same is true for the world scale, according to LinkedIn, the average quit rate in pharmaceutical industry in 2017 was about $9.4 \%$, which is one of the 10 industries with the highest rate in 2017.

Indeed, the motivation of current employees is not much dependent on extrinsic rewards. According to Erez, Gopher, and Arzi (1990), material rewards can also reduce job performance in complex jobs with different goals. In the pharmaceutical field, the pharmacist must perform different objectives at the same time as: building relationships with many departments in the hospital, updating information about doctors, clinical knowledge, competitors and bidding. To perform these tasks, the pharmacist needs to has a flexible and highly adaptable work plan in different situations. Therefore, the need of creating good motivation for pharmacists, managers not only have extrinsic rewards but also need to increase intrinsic motivation for employees. Helping them to feel joy and excitement in the work, leading to be proactive and creative in solving many complicated situations at work.

\section{Literature Review}

\subsection{Leadership and Work Performance}

\subsubsection{Transformational Leadership}

Burns (1978) was the first researcher to distinguish sharply between the transformational leadership and the transactional leadership. That research was conducted on political leaders but it was also used for organizational psychological research. According to Burns (1978), transformational leadership is a process that both leaders and employees help each other to reach higher levels of willpower and motivation. Bass (1985) officially introduced transformational leadership with models and behavioral factors to explain the psychological mechanism of transformative leadership style. He also described how to measure transformational leadership as well as explained how transformational leadership affect employees' motivation and performance. People with transformative leadership styles are leaders who are able to stimulate and inspire employees to achieve results that exceed expectations and develop employee leadership (Bass \&
Riggio, 2006). This is also the definition of transformational leadership used in this study.

The original transformational leadership includes: charisma of leadership (Charisma), intellectual stimulation and individualized consideration (Avolio, Waldman, \& Einstein, 1988). Throughout advanced research, the fourth factor was identified: inspirational motivation. Then, after reviewing to match the concept of transformation, the element "charisma" was changed to "idealized influence" (Barbuto, 1997). In particular, this element consists of two parts based on the cause of attraction: behavior and attributed of the leader (Barbuto, 2005). This study uses the Multifactor Leadership Questionnaire (MLQ form 5X) scale to measure transformational leadership including the 5 factors mentioned above (Bass \& Avolio, 1997). This is a standard measuring tool for evaluating transformative leadership behavior. It was translated and used in many studies.

\subsubsection{Intrinsic Motivation}

Intrinsic motivation is the implementation of an action for the inherent satisfaction rather than for external reasons. When there is an intrinsic motivation, people can act for their passion rather than for external rewards (Ryan \& Deci, 2000). Intrinsic motivation is made up of three main needs: desire to succeed in a field, meaning of action or independence and orientation for own life (Deci \& Ryan, 1985). Promoting intrinsic motivation, especially in the business environment, helps managers in saving time and money, compared to promoting extrinsic motivation in a long term.

\subsubsection{Work Performance}

According to Borman and Motowidlo (1993), work performance includes two aspects: task performance (also called "in-role behavior") and contextual performance (also called "extra-role behavior"). In which, the task performance is the result of carrying out activities that benefit the organization. It can be directly part of the technical process or indirectly through providing materials or services. Work performance of employee is measured by 21 factors developed by Williams and Anderson (1991). This measurement is developed from three aspects of employee behavior: Organizational citizenship behaviors that benefits a specific individual (OCBI); Organizational citizenship behaviors that benefits a specific individual organization (OCBO); In-role behavior (IRB). The manager will evaluate the performance of the employee through a scale of 7 observed variables in IRB. It means task performance (Williams \& Anderson, 1991).

\subsubsection{Idealized Influence (Behavior \& Attributed) and Intrinsic Motivation}

The idealized influence (behavior and attributed) of the leader, who has transformational leadership, is created by the way leaders share their vision, mission and trust, as well as inspire employees about the organization's goals. The 
leader has a transformational leadership with high competence, determination in dealing with problems. Thereby, the pride and dignity of employees are has risen (Ahmad, Abbas, Latif, \& Rasheed, 2014). In this environment, employees will perform appropriate tasks and desire to exceed the assigned goals (Kahai, Sosik, \& Avolio, 2003). Therefore, this study proposes hypothesis number one and number two as below:

H1: The idealized influence (attributed) of leader has a positive effect on intrinsic motivation

H2: The idealized influence (behavio)r of leader has a positive effect on intrinsic motivation

\subsubsection{The Leader's Inspirational Motivation and Intrinsic Motivation}

Leaders with transformational leadership are interested in the feelings and needs of the employees, and guide them to achieve their goals (Bass, 1990). Therefore, the employees are improved their interest in work. Inspirational motivation (IM) is one of the characteristics of transformational leadership, which represents the leader's vision (Bass, 1990). According to Densten (2002), leaders will use their vision to encourage employees to make efforts beyond expectations. Specifically, the leader will use the symbols, metaphors and simple appeals to raise awareness and understanding about common goals of employees. The inspirational ability is that leaders use mental images to evoke vividly the charismatic picture of the future, thereby increasing the motivation of employees to help them achieve outstanding achievements. rank. The inspirational leader also promotes the excitement and meaning of work for employees. According to Shin and Zhou (2003), the inspirational leader will increase the concentration and energy of employees when working. So, proposed hypothesis number three as follow:

H3: Inspirational motivation of leader has a positive influence on intrinsic motivation

\subsubsection{Leader's Intellectual Stimulation and Intrinsic Motivation}

According to Bolkan, Goodboy, and Griffin (2011), the ability of stimulating intelligence is related to intrinsic motivation and this motivation can affect students' ability to learn effectively. The transformational leader with intellectual stimulation ability will stimulate employees to make assumptions, challenge the current ordeal and encourage solving problems; stimulating imagination, curiosity and unique problem approaches (Shin \& Zhou, 2003). Since then, employees have been interested in their work, as well as they have focused on work, and have found better ways. In addition, the challenges of the transformational leaders contribute to increase energy, then they discover and are attracted to many different aspects of work. According to Deci and Ryan (2000), these factors create employees' intrinsic motivation. Thus, hypothesis number four is set as follow:

H4: Intellectual stimulation of leader has a positive influence on intrinsic motivation

\subsubsection{Leader's Individualized Consideration and Intrinsic Motivation}

A final aspect of the transformational leadership is individualized consideration (IC), which includes development orientation for employees and is an important approach for leaders to help their employee in succeeding in the current business environment (Rafferty \& Griffin, 2006). Bass (1985) had argued that individualized consideration included two important aspects: the development of employees and attention to each individual. Bass (1985) said that the development orientation for employees is demonstrated by giving advice, observing the development proce and encouraging employees to join advanced course. On the other hand, individualized consideration is that when the leader cares about the differences between employees and trys to motivate each employee (Bass, 1985).

Therefore, individualized consideration creates the interest, understanding employee's needs, developing their abilities and giving them information and resources to develope themselves. Thus, the leader with transformational leadership will encourage employees, enhance their readiness, concentration and having a good performance. Hypothesis number five is proposed:

H5: Individualized consideration of leader has a positive effect on intrinsic motivation.

\subsubsection{Intrinsic Motivation and Work Performance}

Intrinsic motivation are thought to have stronger effects than extrinsic motivation on persistent efforts (Ryan \& Deci, 2000; Vallerand, 1997). It is an important factor affecting the work performance. Hackman and Oldman (1980) also agreed the positive relationship between intrinsic motivation and work performance. Baard, Deci, and Ryan (2004) also demonstrated the impact of the internal needs of employee (ability, selfdetermination, familiarity) on employee performance.

Intrinsic motivation creates the meaning, commitment and engagement of employees, thereby creating job performance (Chalofsky \& Krishna, 2009). Promoting intrinsic motivation, especially in a complex business field like pharmaceuticals, will not only save money in the longterm period but also create the best connection for employees, hence contributing to enhance performance. The manager will not take much time to control, remind or urge employees every day. Therefore, hypothesis number six is set as bellow:

H6: Intrinsic motivation has a positive effect on work performance. 


\subsection{Research Model}

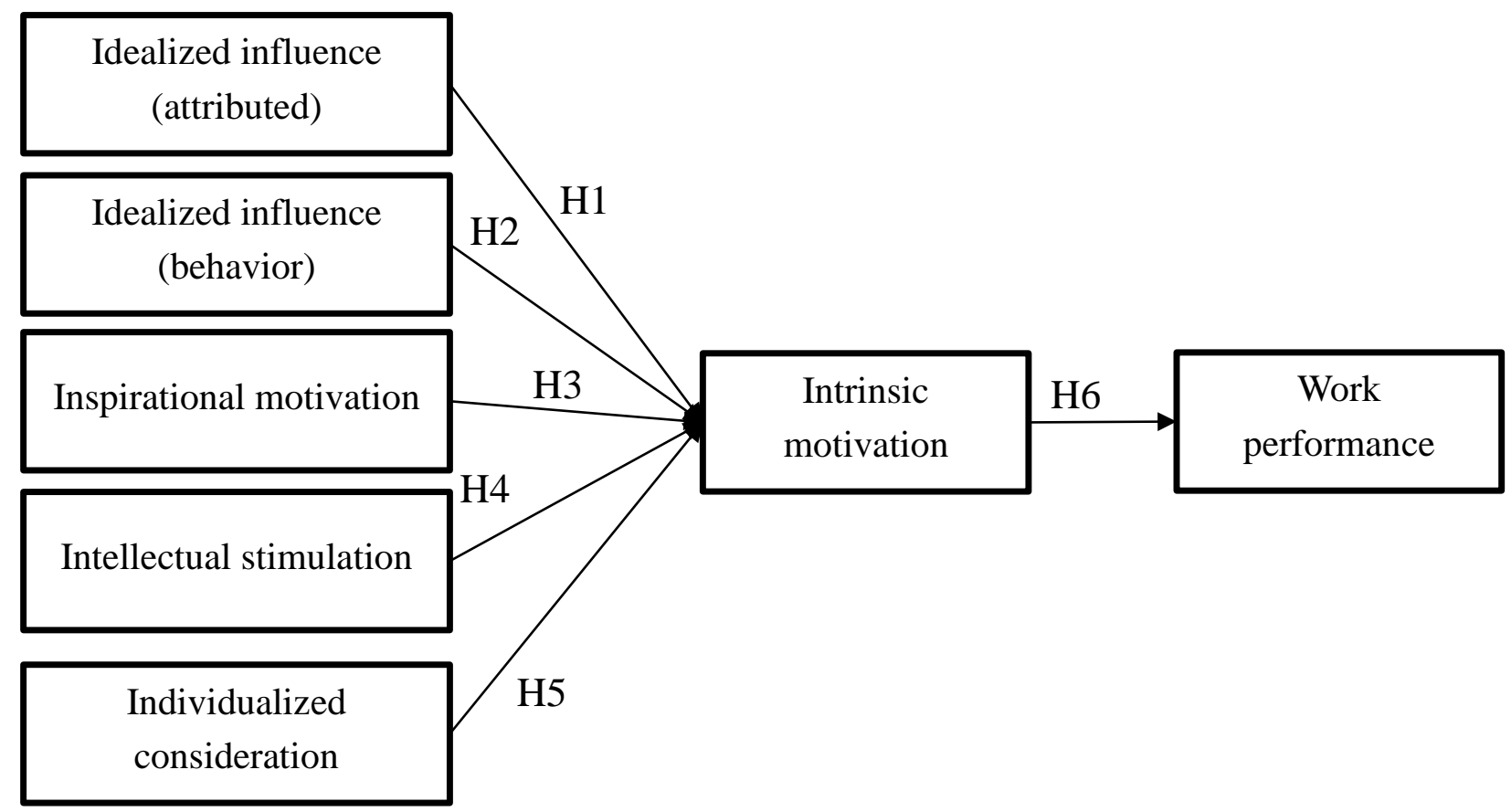

Figure 1: Proposed research model

\section{Research Method}

Both qualitative research and quantitative research are used in this research:

Qualitative research collected data by two me thods, which areinterviews and group discussions. The interviews were conducted with 3 leaders of companies in the pharmaceutical field (Managing Diabetes medicine group - Astra Zeneca representative office; Managing Cancers medicine group - Piere Fabre representative office; Managing eye medicine group - Hyphens Pharma representative office). After that, this study started the second stage, which is group discussion to collect idea from 2 groups (7 peoples and 5 peoples), who were working in pharmaceutical companies, as: Piere Fabre representative office, Boehringer Ingelheim representative office, Servier Vietnam Co. Ltd, Fresenius Kabi representative office, Hoang Duc Co. Ltd, Hyphens Pharma representative office, Astra Zeneca representative office. The result of qualitative research added 11 observed variables (IIa6, IIa7; IIb5, IIb6; IM5; IS5; IC5, IC6; IT5, IT6; WP8) to meassure 7 factors: Idealized influence (attributed) (IIa), Idealized influence (behavior) (IIb), Inspirational motivation (IM), Intellectual stimulation (IS), Individualized consideration (IC), Intrinsic motivation (IT), Work performance (WP).

Quantitative research was conducted by a survey with 250 pharmacists working in pharmaceutical field in Vietnam. Likert five-point scale "1-Totally disagree", "2-Disagree",
"3-Neutral ", "4-Agree", "5. Totally agree" ,is used to measure observed variables in each factor. The collected data would be processed and analyzed by SPSS 20 to assess the significance of factors as well as test the hypotheses.

\section{Results}

There are 250 questionnaires generated and collected, after sorting out unsatisfied forms due to lack of information, the remaining 220 valid questionnaire forms (88\%) used to analyze.

\subsection{Descriptive Statistics}

Gender and age: numbers of male and female are quite similar (male $45.5 \%$ and female $54.5 \%$ ). Most of them are young people, $97.7 \%$ are under 36 years old. There are only 5 people in the group from 36 to 45 years old (Table 1).

Education: The majority of respondents graduated from university, accounting for $79.5 \%$ with 175 people. After that, the group of postgraduate qualifications accounted for $15.9 \%$. The remaining proficiency groups are college and high school with 5 people each.

The amount of income above 20 million VND is relatively high with $28.7 \%$ of total respondents, divided into two groups: from 20 to less than 30 millionVND with 45 people accounting for $20.5 \%$, over 30 millionVND with 18 
people accounting for $8.2 \%$.

Experience and company type: Most respondents have under 10 years of working experience with 205 people, which accounts for $93.2 \%$. And the research samples are mostly working in representative offices of multinational pharmaceutical companies with 159 people accounting for $72.3 \%$.

Table 1: Descritptive statistics

\begin{tabular}{|c|c|c|c|}
\hline & & Frequency & Tỷ lệ (\%) \\
\hline \multirow{2}{*}{ Gender } & Male & 100 & 45.5 \\
\hline & Female & 120 & 54.5 \\
\hline & & & \\
\hline \multirow{3}{*}{ Ages } & $18-25$ years old & 74 & 33.6 \\
\hline & 26 - 35 years old & 141 & 64.1 \\
\hline & 36 - 45 years old & 5 & 2.3 \\
\hline \multirow{4}{*}{ Education } & High school & 5 & 2.3 \\
\hline & College & 5 & 2.3 \\
\hline & University & 175 & 79.5 \\
\hline & Postgraduate & 35 & 15.9 \\
\hline \multirow{4}{*}{ Income } & $<10$ millionVNĐ & 58 & 26.4 \\
\hline & $10-20$ million VNĐ & 99 & 45.0 \\
\hline & 20 - 30 million VND & 45 & 20.5 \\
\hline & $>30$ million VNĐ & 18 & 8.2 \\
\hline & & & \\
\hline \multirow{4}{*}{ Experience } & $<5$ years & 115 & 52.3 \\
\hline & $5-10$ years & 90 & 40.9 \\
\hline & $10-15$ years & 10 & 4.5 \\
\hline & $>15$ years & 5 & 2.3 \\
\hline \multirow{2}{*}{ Company type } & Vietnam's company & 61 & 27.7 \\
\hline & representative office & 159 & 72.3 \\
\hline
\end{tabular}

\subsection{Descriptive Statistic of Quantitative Variables}

Idealized influence (attributed): IIa2 has the highest mean value with 4.05 , while IIa6 gets the lowest mean value of 3.60. Thus, the pharmacists believe that their leaders are more concerned with the advantages of the group than fairness when deciding to solve problems (Table 2).

Idealized influence (behavior): IIb5 has the highest mean value of 3.53, while IIb6 has the lowest lowest value of 3.40. This means that the pharmacists appreciate the leader's ability to protect employees rather than leaders with specific work plans to support each employee to achieve personal goals.

Inspirational motivation: IM4 and IM5 has the same mean value and it is the highest (3.58), while IM2 has the lowest mean value (3.41). Therefore, the pharmacists see that the leaders are confident of reaching their goals and always focus on company's mission consistently rather than talking excitedly about the employees' goals.
Intellectual stimulation: IS2 has the highest mean value (3.53), while IS3 has the lowest mean value (3.48). This means the pharmacists positively evaluate leaders who seek different perceptions when solving problems rather than asking others to look at issues from different perspectives.

Individualized consideration: IC3 gets the highest mean value with 3.59 , while IC2 gets the lowest mean value (2.87). So the pharmacists thinks that the leaders should care about the needs, abilities and aspirations of each employee rather than how to treat individuals..

Intrinsic motiavtion: IT6 has the highest mean value (3.83), while IT2 has the lowest mean value (3.27). Thus, the pharmacists performs the current tasks because they want to contribute to group overall goal rather than interested in task.

Work performance: WP8 has the highest average value (3.82), while WP6 has the lowest (3.21). So, the pharmacists are trying to complete tasks on time more than focusing on the rmandatory tasks. 
Table 2: Descriptive statistic of quantitative variables

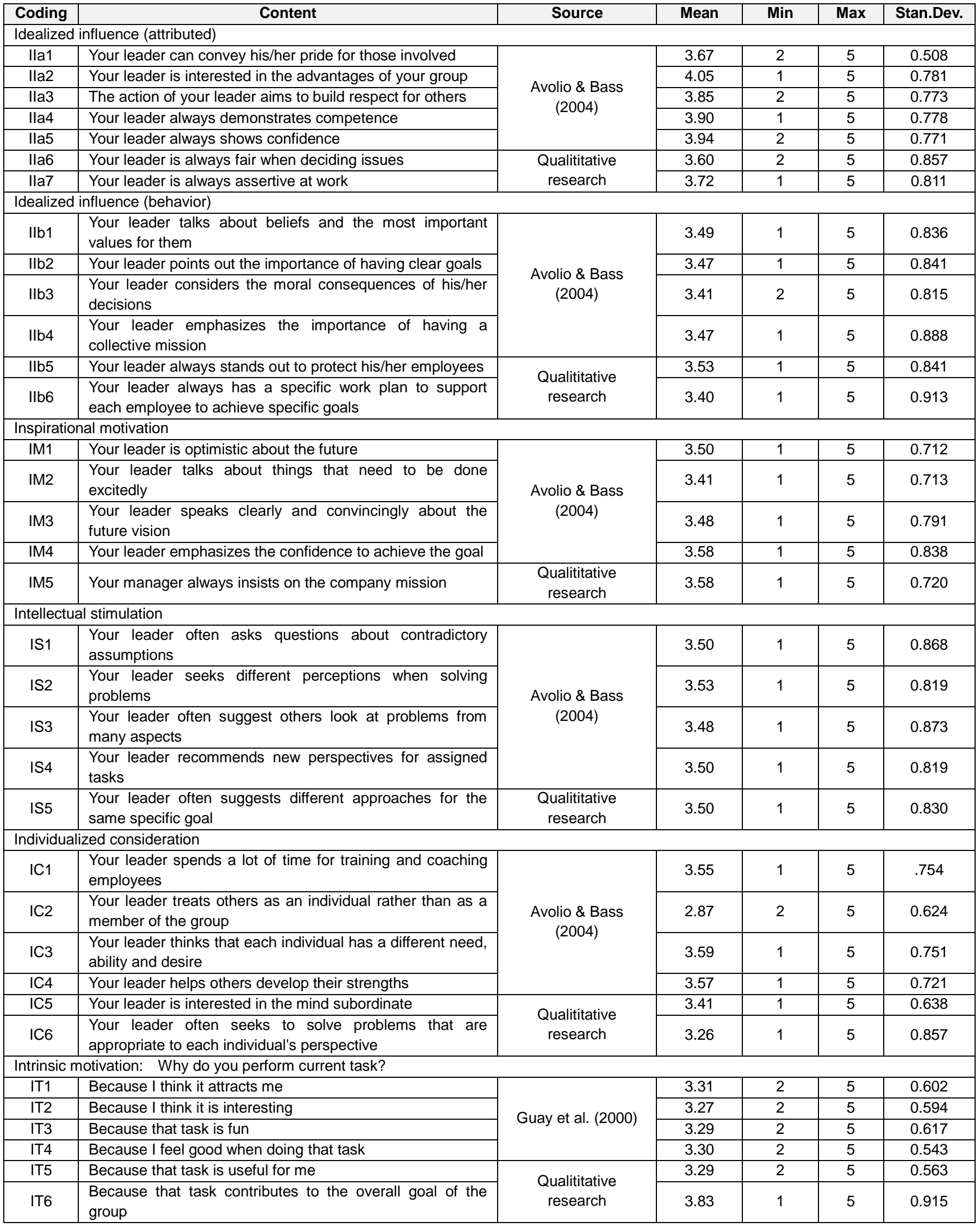


Ha Minh NGUYEN, Lam Tung MAI, Tam Luong HUYNH / Journal of Asian Finance, Economics and Business Vol 6 No 4 (2019) 201-212

\begin{tabular}{|c|c|c|c|c|c|c|}
\hline \multicolumn{7}{|c|}{ Work performance } \\
\hline WP1 & Satisfactory completion level of your assigned tasks & \multirow{4}{*}{$\begin{array}{c}\text { Williams \& Anderson } \\
\text { (1991). }\end{array}$} & 3.30 & 2 & 5 & .671 \\
\hline WP3 & You perform all the expected tasks & & 3.30 & 2 & 5 & 0.614 \\
\hline WP5 & $\begin{array}{l}\text { Your level of commitment to implementing activities that } \\
\text { directly improve work performance }\end{array}$ & & 3.30 & 2 & 5 & 0.627 \\
\hline WP6 & You often focus on mandatory tasks & & 3.21 & 2 & 5 & 0.621 \\
\hline WP8 & You have completed tasks on time. & $\begin{array}{l}\text { Qualititative } \\
\text { research }\end{array}$ & 3.82 & 2 & 5 & 0.692 \\
\hline
\end{tabular}

\subsection{Reliability of Scale and Exploratory Factor Analysis (EFA)}

\subsubsection{Reliability of Scale}

The indicators IIb1, IIb3, IM5, IC2, IT6, WP8 were disqualified because of corrected Item-total correlation less than 0.3 when performing Cronbach's Alpha testing. After that, Cronbach's Alpha coefficients of "Idealized influence (attributed)", "Idealized influence (behavior)", "Inspirational motivation", "Intellectual stimulation", "Individualized consideration", "Intrinsic motivation" and "Work performance" alternatively are: $0.834,0.811,0.748,0.817$, $0.753,0.820,0.922$, which are all more than 0.7 ; all of the observed variables measuring these factors achieve a total correlation coefficient of variables above 0.3. Therefore, those remain observed variables measure the above factors, as shown in Table 3, are all qualified to be added into EFA.

Table 3: Cronbach's Alpha coefficients

\begin{tabular}{|c|c|c|c|}
\hline Observed Variables & Corrected Item-Total Correlation & Cronbach's Alpha if Item Deleted & Cronbach's Alpha \\
\hline \multicolumn{4}{|l|}{ Idealized influence (attributed) } \\
\hline Ila1 & 0.607 & 0.816 & \multirow{7}{*}{0.834} \\
\hline Ila2 & 0.643 & 0.802 & \\
\hline Ila3 & 0.618 & 0.806 & \\
\hline Ila4 & 0.606 & 0.808 & \\
\hline Ila5 & 0.589 & 0.811 & \\
\hline $11 \mathrm{la} 6$ & 0.535 & 0.821 & \\
\hline Ila7 & 0.545 & 0.818 & \\
\hline \multicolumn{4}{|l|}{ Idealized influence (behavior) } \\
\hline Ilb2 & 0.646 & 0.756 & \multirow{4}{*}{0.811} \\
\hline Illb4 & 0.632 & 0.762 & \\
\hline Ilb5 & 0.630 & 0.763 & \\
\hline $\mathrm{Illb6}$ & 0.612 & 0.773 & \\
\hline \multicolumn{4}{|l|}{ Inspirational motivation } \\
\hline IM1 & 0.649 & 0.635 & \multirow{4}{*}{0.748} \\
\hline IM2 & 0.482 & 0.722 & \\
\hline IM3 & 0.542 & 0.691 & \\
\hline IM4 & 0.514 & 0.710 & \\
\hline \multicolumn{4}{|l|}{ Intellectual stimulation } \\
\hline IS1 & 0.641 & 0.770 & \multirow{5}{*}{0.817} \\
\hline IS2 & 0.574 & 0.790 & \\
\hline IS3 & 0.570 & 0.792 & \\
\hline IS4 & 0.634 & 0.773 & \\
\hline IS5 & 0.617 & 0.778 & \\
\hline \multicolumn{4}{|l|}{ Individualized consideration } \\
\hline IC1 & 0.534 & 0.703 & \multirow{6}{*}{0.753} \\
\hline IC3 & 0.563 & 0.693 & \\
\hline IC4 & 0.507 & 0.713 & \\
\hline IC5 & 0.418 & 0.742 & \\
\hline IC6 & 0.577 & 0.688 & \\
\hline IC1 & 0.534 & 0.703 & \\
\hline \multicolumn{4}{|l|}{ Intrinsic motivation } \\
\hline IT1 & 0.655 & 0.771 & \multirow{2}{*}{0.820} \\
\hline IT2 & 0.637 & 0.777 & \\
\hline
\end{tabular}




\begin{tabular}{|c|c|c|c|}
\hline IT3 & 0.638 & \multicolumn{2}{|c|}{0.777} \\
\hline IT4 & 0.498 & 0.815 \\
\hline IT5 & 0.633 & 0.779 \\
\hline Work performance & \multicolumn{2}{|c|}{} \\
\hline WP1 & 0.772 & 0.909 \\
\hline WP2 & 0.751 & 0.911 \\
\hline WP3 & 0.747 & 0.912 & \multirow{2}{*}{0.922} \\
\hline WP4 & 0.781 & 0.908 & \\
\hline WP5 & 0.754 & 0.911 & \\
\hline WP6 & 0.739 & 0.912 & \\
\hline WP7 & 0.759 & 0.911 & \\
\hline
\end{tabular}

\subsubsection{Exploratory Factor Analysis (EFA)}

All observed variables belong to transformational leadership's scale (25 indicators) which were analyzed with Varimax rotation. Since the distinction between two factors IIa and IM is not guaranteed, the observed variable IIa1 was eliminated after the first rotation. Recheck Cronbach's Alpha coefficient of the scale "Idealized influence (attributed)", Cronbach's Alpha $=0.816$ and the correlation coefficient of the remaining variables is qualified $(>0.3)$. The results of $\mathrm{EFA}$, after removing IIa1, were qualified with $\mathrm{KMO}=0.784$, Barlett's test sig. $=0.000$, Total Eigenvalue $=1.318, \%$ Cumulative $=58.136 \%($ Table 4$)$.

Table 4: Result of exploratory factor analysis

\begin{tabular}{|c|c|c|c|c|c|c|}
\hline \multirow{2}{*}{\multicolumn{2}{|c|}{ Component }} & \multicolumn{5}{|c|}{ Component } \\
\hline & & 1 & 2 & 3 & 4 & 5 \\
\hline \multirow{6}{*}{ Idealized influence (attributed) } & Ila4 & 0.736 & & & & \\
\hline & Ila2 & 0.714 & & & & \\
\hline & Ila5 & 0.711 & & & & \\
\hline & Ila3 & 0.707 & & & & \\
\hline & Ila6 & 0.703 & & & & \\
\hline & Ila7 & 0.687 & & & & \\
\hline \multirow{5}{*}{ Intellectual stimulation } & IS4 & & 0.771 & & & \\
\hline & IS1 & & 0.771 & & & \\
\hline & IS2 & & 0.738 & & & \\
\hline & IS5 & & 0.733 & & & \\
\hline & IS3 & & 0.707 & & & \\
\hline \multirow{5}{*}{ Individualized consideration } & IC1 & & & 0.732 & & \\
\hline & IC6 & & & 0.681 & & \\
\hline & IC3 & & & 0.679 & & \\
\hline & IC4 & & & 0.662 & & \\
\hline & IC5 & & & 0.576 & & \\
\hline \multirow{4}{*}{ Idealized influence (behavior) } & Illb6 & & & & 0.794 & \\
\hline & Illb2 & & & & 0.793 & \\
\hline & Illb5 & & & & 0.788 & \\
\hline & Illb4 & & & & 0.774 & \\
\hline \multirow{4}{*}{ Inspirational motivation } & IM1 & & & & & 0.775 \\
\hline & IM2 & & & & & 0.764 \\
\hline & IM4 & & & & & 0.646 \\
\hline & IM3 & & & & & 0.634 \\
\hline
\end{tabular}

Then, this study performed EFA in turn for observed variables belong to scale "Intrinsic motivation" and "Work performance". The results of IM's scale were satisfactory with $\mathrm{KMO}=0.850$, Barlett's test sig. $=0.000$, Total Eigenvalue $=2.911, \%$ Cumulative $=58.216 \%$. Meanwhile, the scale of factors WP, one component was extracted with 7 indicators $(\mathrm{KMO}=0.926$, Bartlett's test sig. $=0.000$, Total Eigenvalue $=4.780, \%$ Cumulative $=68,290 \%$ ).

\subsection{Regression Analysis}

Firstly, this research performed linear regression analysis for the model that transformational leadership affect to intrinsic motivation (Table 5). The results showed that $\mathrm{R}^{2}=0.713$, this mean $71.3 \%$ of "Intrinsic motivation" can be explained by independent variable in this model. In F testing, sig. $=0.000$, so this model suitable with data. The DurbinWatson value was 1.963 and maximum VIF value was 1.384 , so there were no autocorrelation and multicollinearity happening. 
Table 5: The result of transformational leadership affect to intrinsic motivation model

\begin{tabular}{|c|c|c|c|c|c|c|}
\hline \multirow[t]{2}{*}{ Model } & \multicolumn{2}{|c|}{$\begin{array}{l}\text { Unstandardized } \\
\text { Coefficients }\end{array}$} & \multirow{2}{*}{$\begin{array}{l}\text { Standardiz } \\
\text { ed } \\
\text { Coefficient } \\
s(\beta)\end{array}$} & \multirow[t]{2}{*}{$t$} & \multirow[t]{2}{*}{ Sig. } & \multirow[t]{2}{*}{ VIF } \\
\hline & B & Std. & & & & \\
\hline Constant & -0.100 & 0.160 & & -0.623 & 0.534 & \\
\hline $\mathrm{Ila}$ & 0.091 & 0.030 & $0.117^{* * *}$ & 3.043 & 0.003 & 1.101 \\
\hline $\mathrm{Ilb}$ & 0.264 & 0.024 & $0.413^{\text {tat+ }}$ & 10.898 & 0.000 & 1.072 \\
\hline IM & 0.254 & 0.032 & $0.330^{* * * *}$ & 7.832 & 0.000 & 1.321 \\
\hline IS & 0.259 & 0.028 & $0.372^{* * t}$ & 9.392 & 0.000 & 1.170 \\
\hline IC & 0.096 & 0.036 & $0.114^{* * *}$ & 2.653 & 0.009 & 1.384 \\
\hline Dependent variable & \multicolumn{6}{|c|}{ IT } \\
\hline $\mathrm{R}^{2}$ & \multicolumn{6}{|c|}{0.713} \\
\hline Adjusted $\mathrm{R}^{2}$ & \multicolumn{6}{|c|}{0.706} \\
\hline Durbin-Watson & \multicolumn{6}{|c|}{1.963} \\
\hline $\mathrm{F}$ (Anova) & \multicolumn{6}{|c|}{106.296} \\
\hline Sig. (Anova) & \multicolumn{6}{|c|}{0.000} \\
\hline significant at the $1 \%$ level & & & & & & \\
\hline
\end{tabular}

Continue to perform linear regression analysis for intrinsic motivation affect to work performance model. The analytical results showed that $\mathrm{R}^{2}=0.503$ means that $50.3 \%$ of "Work performance" can be explained by "Intrinsic motivation". In F testing, sig $=0.000$, we concluded that the regression model was suitable for the data. The Durbin Watson value $=1.606$, and $\mathrm{VIF}=1$ so there were no autocorrelation and multicollinearity (Table 6).

Table 6: The result of intrinsic motivation affect to work performance model

\begin{tabular}{|c|c|c|c|c|c|c|}
\hline \multirow[t]{2}{*}{ Model } & \multicolumn{2}{|c|}{$\begin{array}{l}\text { Unstandardized } \\
\text { Coefficients }\end{array}$} & \multirow{2}{*}{$\begin{array}{c}\text { Standardized } \\
\text { Coefficients } \\
(\beta)\end{array}$} & \multirow[t]{2}{*}{$\mathbf{t}$} & \multirow[t]{2}{*}{ Sig. } & \multirow[t]{2}{*}{ VIF } \\
\hline & B & Std. & & & & \\
\hline Constant & 0.562 & 0.185 & & 3.032 & 0.003 & \\
\hline Dependent variable & \multicolumn{6}{|c|}{ WP } \\
\hline $\mathrm{R}^{2}$ & \multicolumn{6}{|c|}{0.503} \\
\hline Adjusted $\mathrm{R}^{2}$ & \multicolumn{6}{|c|}{0.501} \\
\hline Durbin-Watson & \multicolumn{6}{|c|}{1.606} \\
\hline $\mathrm{F}$ (Anova) & \multicolumn{6}{|c|}{220.515} \\
\hline Sig. (Anova) & \multicolumn{6}{|c|}{0.000} \\
\hline
\end{tabular}

Idealized influence (attributed) has a positive effect on intrinsic motivation (H1): The factor "Idealized influence (attributed)" with sig. $=0.003$, has a significant at the $1 \%$ level and $\beta 1=0.117>0$, so hypothesis $\mathrm{H} 1$ is accepted. This result is completely consistent with previous researchs by Piccolo and Colquitt (2006), Gumusluogl and Ilsev (2007). In fact, leaders have outstanding qualities such as good ability, passion and enthusiasm for work that will inspire their employees. The pharmacists under these leaders will have the love, passionate about thier work, thereby increasing intrinsic motivation for themselves.

Idealized influence (behavior) has a positive effect on intrinsic motivation (H2): The factor "Idealized influence (behavior)" has a significant level at $1 \%(\mathrm{sig}=0.000)$ and $\beta 2=0.413>0$. Therefore, hypothesis $\mathrm{H} 2$ is accepted. This result fully consistent with earlier studies of Piccolo and Colquitt (2006); Bennis and Nanus (1985). Indeed, the behavior of leaders in pharmaceutical companies will have a strong impact on employees' emotions. Specifically, leaders always clarify the role and importance of building goals or creating more trust for employees, fromthere their employees will have positive feelings in job. At that time, the pharmacists will perform their duties in ways that they find attractive by themselves. It is also when their intrinsic motivation reaches the most positive impact.

Inspirational motivation has a positive affect on intrinsic motivation: the factor "Inspirational motivation" has sig. $=0.000$ and $\beta 3=0.330>0$. Thus, hypothesis $\mathrm{H} 3$ is 
accepted. This is quite similar to previous research by Piccolo and Colquitt (2006). The ability to inspire represents the ability of leaders to use vision (Bass, 1990). Highly inspirational leaders have the ability to use a variety of skills to improve awareness of the pharmacist with respect to their vision, mission or specific goals. At the same time, positive emotions and intrinsic motivation also enhanced.

Intellectual stimulation has a positive effect on intrinsic motivation: "Intellectual stimulation" statistical meaning was at $1 \%$ (sig. $=0.000)$; and $\beta 4=0.372>0$, proving that hypothesis $\mathrm{H} 4$ is accepted. This result is similar to previous studies by Piccolo and Colquitt (2006); Bolkan and Goodboy (2011). In fact, that the leaders who are able to stimulate the intelligence of the pharmacist will create the ability to analyze and deduce. From there, the pharmacisst can make effective plans to meet many goals. Therefore, the pharmacists get proactive feeling while performing their tasks, increase intrinsic of ourselves.

Individualized consideration has a positive effect on intrinsic motivation: "Individualized consideration" statistical meaning was at $1 \%$ (sig. $=0.009$ ); and $\beta 5=0.114>$ 0 , proving that hypothesis $\mathrm{H} 5$ is accepted. Thus, the hypothesis H5 is accepted. This result is entirely consistent with earlier researchs by Piccolo and Colquitt (2006); Rafferty and Griffin (2006). In pharmaceuticals field, leaders care about their staff to help them share a view together. Thence, the pharmacists enhance their emotional, intrinsic motivation. Besides, individualized consideration will help managers realize the characteristics and outstanding qualities inside the pharmacist. Thereby, the leaders can help their staff to have a clearly orientations in the future and in their daily life. The pharmacists, with positive emotions, will work hard and contribute to company. In other words, the intrinsic motivation of pharmacist reachs a higher level.

Intrinsic motivation has a positive effect on work performance (H6): The factor "intrinsic motivation" has sig $=0.000$ and $\beta 6=0.709$, so the hypothesis H6 is accepted. There was a similar result in previous studies by Hackman and Oldman (1980); Piccolo and Colquitt (2006). The intrinsic motivation will create a positive emotional connection between pharmacists and work. The pharmacists will achieve their commitment and engagement to tasks. They themselves feel urged, motivated during the implementation of their tasks without extrinsic motivation factors. The employees will work more efficiently, so improving work performance.

\section{Conclusion and limitation}

\subsection{Conclusion}

The research model includes 5 factors of transformat ional leadership, which affect work performance toward intrinsic motivation of employees working in the phar maceutical field in Vietnam. These above factors are $\mathrm{m}$ easured by 43 observed variables. However, after testin g scale's reliability and Exploratory Factor Analysis, the re were 7 eliminated observed variables, so the final ob served variables used in regression analysis were 36 . $T$ he results of multivariate regression analysis showed the Idealized influence (attributed and behavior); Inspiratio nal motivation; Intellectual stimulation; Individualized co nsideration all have a positive impact on intrinsic motiv ation. And intrinsic motivation has a positive affect on work performance. It confirms that employees will have a higher intrinsic motivation level when working under transformational leadership from their leaders. It makes employees work more efficiently.

Regrading the results, this study propose some management suggestions that can improve employee's intrinsic motivation through the transformational leadership, thereby increasing work performance. The leader needs to have a positive vision and find out the advantages of the group, thus ncouraging the group to work better, achieving higher performance. Besides, leaders should consider and be willing to stand up for their employees when encountering conflicts in working process. This will make employees admire their leaders more, since then employees have more motivation to perform their tasks. Furthermore, the leaders should be confident with their own ability and consistency with company's goals. It contributes to inspiring employees to feel confident when working. Therewith leaders should look for different perspectives when solving a problem, which makes employees feel more respectful, creating more positive emotions when working. Finally, leaders should actively explore the needs, abilities and aspirations of employees, which is the basis for assigning tasks and orienting work as well as creating emotional engagement. Pharmacists must see the impact of their contributions to the overall goal, thence enhancing positive intrinsic motivation and work performance.

\subsection{Limitation}

Firstly, this study only considers the impact of transformatioal leadership on work performance toward intrinsic motivation without considering other motivations. Secondly, this study focused on considering the impact of transformational leadership without considering other leadership styles. Finally, this study uses a convenient sampling method that also has a certain limitation. The generalization of research results will be higher if done by random sampling.

\section{References}

Ahmad, F., Abbas, T., Latif, S., \& Rasheed, A. (2014). Impact of transformational leadership on employee motivation in telecommunication sector. Journal of 
Management Policies and Practices, 2(2), 11-25.

Avolio, B. J., Waldman, D. A., \& Einstein, W. O. (1988). Transformational leadership in a management game simulation: Impacting the bottom line. Group \& Organization Studies, 13(1), 59-80.

Baard, P. P., Deci, E. L., \& Ryan, R. M. (2004). Intrinsic need satisfaction: A motivational basis of performance and Weil-Being in two work settings. Journal of Applied Social Psychology, 34(10), 2045-2068.

Barbuto Jr., J. E. (2005). Motivation and transactional, charismatic, and transformational leadership: A test of antecedents. Journal of Leadership \& Organizational Studies, 11(4), 26-40.

Barbuto, J. E. (1997). Taking the charisma out of transformational leadership. Journal of Social Behavior and Personality, 12(3), 689-697.

Bass, B. M. (1985). Leadership and performance beyond expectations. New York, NY: Collier Macmillan.

Bass, B. M. (1990). From transactional to transformational leadership: Learning to share the vision. Organizational Dynamics, 18(3), 19-31.

Bass, B. M., \& Avolio, B. J. (1997). Full range leadership development: Manual for the Multifactor Leadership Questionnaire. Menlo Park, CA: Mind Garden.

Bass, B. M., \& Avolio, B. J. (2004). Multifactor Leadership Questionnaire: MLQ; Manual and Sampler Set. Menlo Park, CA: Mind Garden.

Bass, B. M., \& Riggio, R. E. (2006). Transformational leadership. Mahwah, NJ: Psychology Press.

Bennis, W., \& Nanus, B. (1985). The strategies for taking charge. Leaders. New York, NY: Harper \& Row.

Bolkan, S., \& Goodboy, A. K. (2011). Behavioral indicators of transformational leadership in the college classroom. Qualitative Research Reports in Communication, 12(1), 10-18.

Bolkan, S., Goodboy, A. K., \& Griffin, D. J. (2011). Teacher leadership and intellectual stimulation: Improving students' approaches to studying through intrinsic motivation. Communication Research Reports, 28(4), 337-346.

Borman, W. C., \& Motowidlo, S. M. (1993). Expanding the criterion domain to include elements of contextual performance: Personnel Selection in Organizations. San Francisco, CA: Jossey-Bass.

Burns, J. M. (1978). Leadership. New York, NY: Harper \& Row.

Chalofsky, N., \& Krishna, V. (2009). Meaningfulness, commitment, and engagement: The intersection of a deeper level of intrinsic motivation. Advances in Developing Human Resources, 11(2), 189-203.

Deci, E. L., \& Ryan, R. M. (1985). Intrinsic motivation and self-determination in human behavior. New York, NY: Springer Science \& Business Media.

Deci, E. L., \& Ryan, R. M. (2000). The" what" and" why" of goal pursuits: Human needs and the self-determination of behavior. Psychological Inquiry, 11(4), 227-268.

Deci, E. L., \& Ryan, R. M. (2010). Intrinsic motivation. The
Corsini Encyclopedia of Psychology. [Online First] https://doi.org/10.1002/9780470479216.corpsy0467

Densten, I. L. (2002). Clarifying inspirational motivation and its relationship to extra effort. Leadership \& Organization Development Journal, 23(1), 40-44.

Erez, M., Gopher, D., \& Arzi, N. (1990). Effects of goal difficulty, self-set goals, and monetary rewards on dual task performance. Organizational Behavior and Human Decision Processes, 47(2), 247-269.

Guay, F., Vallerand, R. J., \& Blanchard, C. (2000). On the assessment of situational intrinsic and extrinsic motivation: The Situational Motivation Scale (SIMS). Motivation and Emotion, 24(3), 175-213.

Gumusluoglu, L., \& Ilsev, A. (2009). Transformational leadership, creativity, and organizational innovation. Journal of Business Research, 62(4), 461473.

Hackman, J. R., \& Oldham, G. R. (1974). The Job Diagnostic Survey: An instrument for the diagnosis of jobs and the evaluation of job redesign projects (Yale University Working Paper). Retrieved from https://files.eric.ed.gov/fulltext/ED099580.pdf

Hackman, J. R., \& Oldham, G. R. (1980). Work redesign. Reading, MA: Addison-Wesley.

Kahai, S. S., Sosik, J. J., \& Avolio, B. J. (2003). Effects of leadership style, anonymity, and rewards on creativityrelevant processes and outcomes in an electronic meeting system context. The Leadership Quarterly, 14(4-5), 499524.

Kotter, J. P. (1998). Winning at change. Leader to leader, 10(Fall), 27-33.

Northouse, P. G. (2018). Leadership: Theory and practice. Thousand Oaks, CA: Sage publications.

Piccolo, R. F., \& Colquitt, J. A. (2006). Transformational leadership and job behaviors: The mediating role of core job characteristics. Academy of Management Journal, 49(2), 327-340.

Qiao, Y. (1999). Interstate fiscal disparities in America: A study of trends and causes. New York, NY: Routledge.

Rafferty, A. E., \& Griffin, M. A. (2006). Refining individualized consideration: Distinguishing developmental leadershipand supportive leadership. Journal of Occupational and Organizational Psychology, 79(1), 37-61.

Rafferty, A. E., \& Simons, R. H. (2006). An examination of the antecedents of readiness for fine-tuning and corporate transformation changes. Journal of Business and Psychology, 20(3), 325-350.

Ryan, R. M., \& Deci, E. L. (2000). Intrinsic and extrinsic motivations: Classic definitions and new directions. Contemporary Educational Psychology, 25(1), 54-67.

Shin, S. J., \& Zhou, J. (2003). Transformational leadership, conservation, and creativity: Evidence from Korea. Academy of Management Journal, 46(6), 703-714.

Tannenbaum, R., \& Massarik, F. (1957). Leadership: A frame of reference. Management Science, 4(1), 1-19. 
Vallerand, R. J. (1997). Toward a hierarchical model of intrinsic and extrinsic motivation. In Advances in Experimental Social Psychology (Vol. 29, pp. 271-360). Cambridge, MA: Academic Press.

Williams, L. J., \& Anderson, S. E. (1991). Job satisfaction and organizational commitment as predictors of organizational citizenship and in-role behaviors. Journal of Management, 17(3), 601-617.
Wren, A. (1995, August). Scheduling, timetabling and rostering - a special relationship? In International Conference on the Practice and Theory of Automated Timetabling (pp. 46-75), Dates, City, Country.

Wren, A. (1995, August). Scheduling, timetabling and rostering - A special relationship? In E. Burke \& P. Ross (eds), Practice and Theory of Automated Timetabling. (pp. 46-75). Berlin, Germany: Springer. 